\title{
INTANGIBLE DETERMINANTS OF COMPETITIVENESS AMONG COUNTRIES DURING POST-INDUSTRIAL AGE: THE THEORETICAL ASPECT
} НЕМАТЕРІАЛЬНІ ДЕТЕРМІНАНТИ КОНКУРЕНТОСПРОМОЖНОСТІ КРАЇН
В ПОСТІНДУСТРІАЛЬНУ ДОБУ: ТЕОРЕТИЧНИЙ АСПЕКТ

UDC 339.97

https://doi.org/10.32843/infrastruct37-16

\section{Fedun Igor}

Doctor of Economic Sciences, Professor, Professor of the Department

of World Economy

Kyiv National University of Trade

and Economics

Kudyrko Liudmyla

Candidate of Economic Sciences,

Professor,

Professor of the Department

of World Economy

Kyiv National University of Trade

and Economics
The article describes the newest trends of public request on promulgation of state success' idea in the light of intangible achievements. The main purpose is systematization of approaches which disclose the role of intangible factors in the formation of the country competitive status. For this, combination of the procedural and institutional approaches was applied. Priority lines of the country image building in the international scene through internal and external determinants were identified. The discovery of a new quality of determinants which directed on the international competitiveness of countries' elevation in the twenty-first century has made it possible to identify the link between telic measures of national regulatory policies of intangible assets development and the potential for transformation of countries' place in the international rating system. The practical significance of the article is defined as quality improving of managerial decision-making system at the macro level in modern Ukraine. The further prospects of research are perceived in revealing the link between traditional and modern factors of the state competitive status development by means of economical and mathematical modeling.

Key words: inclusive development index, intangible factors of economic development, competitive advantages, international rankings, soft power strategy, brand of the country.

В статье рассмотрены новейшие тренды общественного запроса на популяризацию идеи успеха государств по критериям нематериальных достижений. Целью исследо- вания является систематизация подходов к раскрытию роли нематериальных фракторов срормирования конкурентного статуса стран. Использованы комбинаторика процессуального и институционального подходов. Через раскрытие внешних и внутренних детерминант определены приоритетные направления формирования имиджа страны на международной арене Практическая значимость представленного исследования обусловлена направленностью на повышение качества и обоснованности системы принятия управленческих решений на макроуровне в современной Украине. Раскрытие нового качества детерминант повышения международной конкурентоспособности стран в условиях XXI века позволила выявить связь между челенаправленными мерами национальных регуляторных политик по развитию и поддержке нематериальных активов и потенциалом трансформации места стран в системе международного рейтингирования. Перспективы дальнейших исследований усматриваются в проведении экономико-математического моделирования на основе статистических данных и оценок международного рейтингов стран для выявления связи между традичионными и новейшими фракторами формирования конкурентного статуса государства. Ключевые слова: индекс инклюзивного развития, нематериальные фракторы экономи ческого развития, конкурентные преимущества, международные рейтинги, стратегия «мягкой силы»), бренд страны.

У статті розглянуто новітні тренди суспільного запиту на популяризацію ідеї успіху держав за критеріями нематеріальних здобутків шляхом глобальної експансії національних культур. Визначено, що в епоху тотальної інформатизації та активної розбудови міжнародних виробничих та збутових мереж джерела формування національного продукту виходять за межі внутрішніх ринків та характеризують собою складний комплекс екзо - та ендогенних факторів, ресурсів та умов. Метою дослідження є систематизація теоретичних підходів до розкриття змісту нематеріальних фракторів формування конкурентного статусу країн, ідентисрікація механізму впливу технологій «м'якої сили» на конкурентоспроможність країн в сучасну добу. Для розкриття теоретико-методологічних засад посилення ролі нематеріальних детермінант конкурентоспроможності країн із виокремленням новітніх ї складових (культура, освіта, бренд країни тощо) використано комбінаторику процесуального та інституціонального підходів та принципи компаративного аналізу. Результати дослідження засвідчили багатоваріативність інтерпретації поняття «м'якої сили» Через розкриття зовнішніх і внутрішніх детермінант використання технологій «м'якої сили», їх тактичних та стратегічних цілей, інструментів та методів реалізації, визначено необхідність використання нематеріальних детермінант як пріоритетних засобів формування іміджу країни на міжнародній арені. На основі ознайомлення із даними міжнародних рейтингів та статистики національних статистичних служб обгрунтовано тезу щодо результативності використання технологій «м'якої сили» в державній політиці низки країн (Франція, КНР, Південна Корея, окремі країни BRICS тощо.) Практична значущість представленого дослідження зумовлюється спрямованістю на підвищення якості та обгрунтованості системи прийняття управлінських рішень на макрорівні в сучасній Україні, а саме шляхом методологічного підгрунтя для модернізації національної стратегії, яка відбиватиме новітні тренди в системі державного регулювання. Перспективи подальших досліджень вбачаються у проведенні економіко-математичного моделювання на основі статистичних даних та оцінок міжнародного рейтингів країн задля виявлення зв'язку між традиційними (матеріальними) та новітніми (нематеріальними) фракторами фрормування конкурентного статусу держави та його зміни в постіндустріальну добу.

Ключові слова: індекс інклюзивного розвитку, нематеріальні фрактори економічного розвитку, конкурентні переваги, міжнародні рейтинги, стратегія «м'якої сили», бренд країни.

Formulation of the problem. The status of the national economy in the system of international economic relations is traditionally equated with its resource potential, economic and military power. These criteria are at the top of national regulatory policies, which basic international ranking of countries is being implemented on, distinguishing groups of countries in for global leaders and outsiders. At the same time, in the context of unprecedented risks of global development of the $21^{\text {st }}$ century, due to the high level of interdependence between countries, the enhancement of the status of a particular state cannot be achieved by attaining higher national indicators, expenditures on the military sphere including financing nuclear weapons from year to year. Determinants of sustainable social and economic develop- 
ment, ideological persuasiveness and attractiveness of national standards and priorities for the consumer, and entrepreneurial culture are gaining increasing importance.

The discourse on the necessity for replacement of the established approach to measuring national economic success of countries during the age of post-industrial transformation, strengthening of the role of informal institutions in providing well-being of the nations and their international competitiveness have been presented for more than a decade, both in the scientific expert environment and on the level of representatives of responsible international organizations. Some steps have already been taken in this direction. In particular, the World Economic Forum in Davos, Switzerland (2018), presented an alternative system at a certain extent for assessing the economic development of countries, which takes into account a wider range of determinants of its provision. This is the "Inclusive Development Index" [1] as a prototype of gross domestic product (GDP), still being the main economic indicator to determine the position of the country in the world. Its mission is he clear identification of the achievement of a society in sustainable and inclusive economic development that takes into account economic and social, environmental, and ultimately civilizational successes, as it is based not only on GDP, but also on more than eleven parameters.

During the last few years another approach to assessing the competitive status of countries in the modern era of total informatization and intensive transcontinental movements of labor, tourists and students has been recognized. It is embodied into the calculation of the "soft power" index of countries, for which international rankings have been formed through several years in a row. This index reflects the latest public demand for the promotion of the idea of national success, whereby not just along with the criteria of economic achievements of any country, but bearing in mind the importance of global expansion of its culture into the broad outlook. Therefore, the soft power modernization state policy, which we identify as a set of measures for the realization of national interests by attracting some special set of intangible resources, culture, beliefs and political ideals to influence the population of foreign countries without involving more traditional elements of force into action, is increasingly supported, including military pressure.

It is quite logical question on the potential of new approaches influencing upon the competitive status of the national economy within post-industrial times, particularly in terms of the validity of the soft power determinants.

Analysis of recent research and publications. Contribution to the study of problems on new approaches to the identification of the civilization success of countries or their groups at the breakthrough of technological structures and transformational shifts in the global economy by the end of the twentieth and on the edge of the early twenty first century were made by such well-known scholars like I. Wallerstein [2], F. Fukuyama, L. Brown and S. Huntington. Conceptual principles for the analysis of the phenomenon of the soft power technologies and their introduction into the regulatory policy of the countries of the world community were developed by such scientists like J. Nay, R. Keohane, A. Cohen, J. Mettern, I. Parmar, S. Walt. Theoretical investigations on specific sectoral aspects of the use of soft power technologies in the context of issues of influence on individual national cultures, ideologies, tourism are reflected in the works of Fraser, P. van Ham, K. Hill, N. Snow, O. A. Chugayev.

Empirical generalizations of the successes of the world countries on the soft power performance criterion are presented by the "Portland" organization, which cooperates with governments, foundations and non-governmental organizations in its annual "A global ranking of Soft Power" analytical report, which presents international ratings. Despite significant foreign and domestic research, in-depth analysis requires assessing the impact of traditional (on the basis of GDP) and recent (soft power index) determinants of improving the competitive status of countries.

The purpose of the study (problem statement) is to systematize theoretical approaches to the disclosure of the content of intangible factors for the formation of competitive status of countries to identify the content and mechanism of influence of "soft power" technology upon the competitive status of countries in the current era.

Research results. In the context of multidimensional and interdependent functioning of national states as elements of modern global economy, strengthening of one's own status through the opened up application of economic coercion or military force to other countries is at least being complicated from the point of view of institutional, financial, economic, environmental and some other constraints. The "hard power" traditionally identified as economic power and "military coercion" can no longer influence the desire of particular states to achieve their goals in the fight for strategic resources and products. Instead, as the developers of the new annual ranking point out, the ability to encourage, cooperate and build effective relations networks of among countries is turning into a new currency in the context of global relations [3].

When analyzing historical dynamics of the ratio of the resources of "soft" and "hard" powers in contemporary professional literature, it is accepted to emphasize such a trend as the decrease in the value of "hard power" within international communications and the increase within the importance of "soft power". It is closely connected to the fact that after the Second World War the UN organization was created 
as the system of regulation of international relations, the main purpose of which is to save future generations from disasters of war. Since then, the priority of the state development has been to increase its own competitiveness using predominantly non-military methods. The growing importance of "soft power", according to D. M. Gallarotti [4], also defines such circumstances like globalization (characterized by the interdependence of states, the high speed of information transfer); the democratization and the spread of liberal principles (not just favoring to soft principles, but also restricting leaders from using force and bribery); huge costs of using nuclear weapons; striving for prosperity and stability of modern Western societies; increasing the role of international organizations, prioritizing multilateralism over a one-sided approach.

Back in the late '80s, American political scientist Joseph Nay introduced the term "soft power" as the ability of a country to persuade others to do what they do not want, without force or coercion. Today, in that kind of scientific literature there is no clarity on the meaning of "soft power". Thanks to the concept of J. Nay, "soft power" can be considered as a derivative of the country's three resources: its culture, political ideology and foreign policy. One of the more updated options for the definition of soft power is to consider this concept as a complex multilevel system that allows the state to solve its tactical and strategic tasks on the international arena in both formal and informal directions [5].

It is advisable for the countries that there are many variants of interpretation of "soft power" by representatives of the world expert community. Such great nations as the China, France and Great Britain claim that the main function of the "soft power" is enshrined in their own historical development. The shortest definition of the term "soft power" sounds like "The ability to attract", i. e. the ability to capture (seize). In other words, political use of force based on cultural influence deserves trust for proposals on interstate cooperation.

Various ways of influencing consciousness, methods of non-violent exercise of power have been known for a long time: N. Machiavelli and the French encyclopedists like G. Toro and M. Gandy, T. Leary and R. Wilson wrote about it in different times. J. Nay managed to uncover nature and role of "soft power" in the mid-twentieth century and point out its limitless possibilities in the $21^{\text {st }}$ century. For a long time J. Nay has been forming the "smart power" order for the White House administration, understanding it as "the ability to combine hard and soft power resources into successful strategies in different contexts" [6].

The genesis of the "soft power" phenomenon is directly related to the concept of "power". The practice of exacerbation among civilizational, ethnic, denominational, etc. conflicts of the last decades has led to the emergence of public demand for a new under- standing of the meaning of "power" as a category of relations. At present day international relations theory and practice offers different approaches to the definition of "strength", but mostly "power" means the ability to make one's will stronger and to impose it to the weak, thereby changing the nature of the relationship in their favor. Proponents of the concept of political realism (R. Gilpin, D. Singer, H. Kissinger, G. Morgenthau, A. Organskiy, B. Rosset, A. Wolffers, etc.) try to portray power as a certain amount that can be calculated [7]. Critics of realism believe that the pecularities like culture, national morality or the quality of diplomacy, including that of government, cannot be accurately accounted for, and the calculations are going to be based on subjective estimates rather than objective, mathematically grounded results.

Leading American political scientists J. Nay and R. Keohane investigate the essence of "power" just in the context of structuralistic approach and propose to derive it from the ideas developed within the theory of interdependence [8]. They believe that the power of the state cannot be equated to military power only, because it constantly shifts from one sphere to another, for example from the military sphere to the economic one.

Although there are multivariate approaches to the implementation of the strategy of interstate interaction in the political space, they are all based on the concept of "force", which at the same time has a different meaningful content. Recent trends in soft politics at international level are widespread: the state, taking care to implement its own national interests and enhance its competitiveness, is seeking for qualitatively new resources in order to influence other participants within international economic relations.

Emphasizing on the components of the contemporary methods of soft power strategies bearing in mind enhancing international competitiveness of countries, it is important to emphasize that such a strategy is being increasingly implemented into the foreign economic policies of countries seeking for enhance or at least maintain their own competitive status. J. Nay emphasized that the rise of post-colonial states usually causes concern and fear for existing countries-leaders. The key way to dispel such fears is, firstly, to take a responsible approach into action, and,secondly, to use "soft power".

Soft power strategies can be considered as a set of external and internal determinants of the stipulation for the welfare of the state and its international competitive status.

External determinants include the following: foreign policy and authority in international affairs; position in the global hierarchy and geopolitical status of the country; civilizational status (there is national culture in every country, but not all countries are the heirs of a particular civilization); political and economic model of state development; state develop- 
ment strategy and ability to put it into practice; information resources of the country, its communication mobility and location on the Great Communication Highway.

Internal (socio-cultural) determinants form such components as ideology; style, quality and standard of living; values (including the national idea); the mentality of the nation; culture of the country (art, literature, film industry, theater, show business); state creative potential: the ability to generate ideas and technologies, including the creative power of the nation.

In soft power, when meaning its concentrated form, the national idea of the country and its mission in the global world has expression. The combination of these factors contributes to the creation of attractive and effective image of the country.

Generalizing approaches uncovering the nature of "soft power" allows us to outline such manifestations like:

- the use of intangible assets to implement one's interests and strategies in the global world;

- the way to achieve the desired foreign policy result peacefully;

- the way of non-violent pursuing national interests into the global world.

Analysis of the empirical evidence of international practice on the implementation of the most important tactical tasks of "soft power" at the level of individual states [9-13] allows us to affirm that one of the effective instruments within the framework of the outlined strategies is the creation of attraction, including the construction of effective image of the country and influence on the object of management as well.

But in this context, the soft power instrument is quite variable, in particular, it goes about information streams; political PR targeted onto foreign audience; active use of global marketing approaches by national companies; positioning the country in the global hierarchy; the language of the country and the degree of its popularity in the world; popular (public) diplomacy; tourism, sports and cultural exchanges; education system and student (youth) exchanges; ability to wage information wars; balanced migration policy; cooperation with the national diaspora; active and purposeful support on the state level for cultural dialogue [14-15].

Soft Power, as a comprehensive indicator of global intangible impact on the country's international status, brings together over 75 indicators nowadays, including objective data and international surveys [3]. If $\mathrm{J}$. Nay defines culture, political ideals, and politics as the three pillars of the country's soft power, so the "Portland" experts suggest, base themselves on J. Nay's assumption, to expand its criteria and manifestations, including index of international tourists' dynamics in the country, direct foreign investment, international assistance, literacy rate and political freedom.
It is important to emphasize that the objectivity of these soft power studies is that they are generated through the information streams from various sources and they cover up information on the government, culture, global involvement of the country's community, education, the prevalence of digital technology and entrepreneurship. Considering the information given above, we emphasize that among these indices, achievement and volume of cultural output are the most important for building the soft power. This index includes cultural activities that help to capture both the quality and the international penetration of cultural production into the country.

In conditions of resilient architectonics in the global political and economic space, we suggest that the importance of soft power as a general strategy for enhancing the competitive status of individual states is to grow further. Soft power is one of the main building blocks of a country's reputation on the international arena; Communication strategies put these resources onto the forefront, which ultimately enables soft power methods and technologies to influence a particular political position or to inspire action. The soft power strategy effectively utilizes the country's communication resources, resulting in more tangible international influence.

Conclusions and prospects of further research. The analysis of theoretical and practical aspects of identification of the content and the mechanism for introduction of soft power technologies (intangible components of national macro-regulation) on their competitive status of the countries allows drawing the following conclusions:

- there is no generally accepted interpretation of the essence and content of "soft power" in the professional contemporary literature as well as in the expert environment, and there is much variability in its interpretation;

- the discovery of the external and internal determinants of the use of soft power technologies, their tactical and strategic goals, instruments and methods of implementation gives possibility to be identified as one of modern and effective means for making country's image on the international arena;

- basing on the analysis of international statistics and country empirical data, the success of individual regulatory policies in applying soft power technologies to enhance their international status can be recognized (China, South Korea, some BRICS countries, etc.)

Prospects for further research are seen in conducting economic and mathematical modeling based on statistics and estimations of the international ranking of countries in order to identify the link between the traditional (material) and the latest (intangible) factors of the state's competitive status and its change in the post-industrial age. 


\section{REFERENCES:}

1. The Inclusive Development Index 2018/World Economic Forum https://www.weforum.org/.../theinclusive-development-inde (accessed 12 October 2019).

2. Immanuel Wallerstein on World-Systems, the Imminent End of Capitalism and Unifying Social Science (2011) Theory Talks- Publisher: University of California Press.

3. A global ranking of Soft Power (2018) URL: https://softpower30.com/wp-content/uploads/ 2018/07/ The-Soft-Power-30-Report-2018.pdf 12 August 2019).

4. Giulio Gallarotti. (2010) Cosmopolitan Power in International Relations: A Synthesis of Realism, Neoliberalism, and Constructivism - NY: Cambridge University Press. pp.34-37.

5. Soft Power: The Means to Success in World Politics, by Joseph S. Nye, Jr. - NY: Public Ajfairs. (2004).

6. Rusakova O. F., Kovaleva D. M. (2013) "Soft power" and "smart power": conceptual analysis. Society and Power. Vol.3 pp. 15-19.

7. Soft Power: The Means to Success in World Politics. Available at: https://www.foreignaffairs.com/ reviews/capsule-review/2004-05-01/soft-power-meanssuccess-world-politics (accessed 11 October.2019).

8. Robert O. Keohane, Nye Jr., Joseph S. Power \& Interdependence (4th Edition) - Publisher: Pearson, 2011. - 368 p. (in English)

9. Kovba D. M. Soft Power in Chinese Political Science and Practice. Available at: http://elar.urfu.ru/ bitstream/10995/46754/1/klo_2017_223.pdf (accessed 30 September 2019).

10. Deepak Chhabra. Soft power analysis in alienated borderline tourism (2017) Journal of Heritage Tourism. pp. 289-304. Available at: https://www.tandfonline.com/ doi/abs/10.1080/1743873X.2017.1337775 (accessed 29 September 2019).

11. Suweon Kim. The misadventure of Korea Aid: developmental soft power and the troubling motives of an emerging donor. Available at: https://www.tandfonline.com/doi/full/10.1080/0143659 7.2019.1622410 (accessed: 12 October 2019).

12. Chatin M., Gallarotti, GM 2016, 'The BRICS and soft power: an introduction' Journal of Political Power, pp. 1-18. DOI: 10.1080/2158379X. ... KW - power. $\mathrm{KW}$ - smart power. KW - soft power. Available at: http://www.scopus.com/inward/record.url?scp=849883 53557\&partnerID=8YFLogxK.U2-10.1080/2158379X. 2016.1232284. (accessed 22 October 2019).

13. Boris Pavlovsky. Austrian foreign cultural policy: Europeanization through the prism of national interests. Available at: https://doi.org/10.1080/10286632.2018.15 49239.

14. Anholt, S. (2007) Competitive identity: the new brand management for nations, cities and regions. New York: Palgrave Macmillan.

15. Anholt, S., 2014. The Anholt-Gfk Roper nation brands index. Available at: http://www.gfk.com/en-cl/ insights/press-release/germany-knocks-usa-off-bestnation-top-spot-after-5-years-1/ (accessed 22 October 2019). 
Doctor of Economic Sciences, Professor, Professor of the Department of World Economy Kyiv National University of Trade and Economics

Kudyrko Liudmyla

Candidate of Economics, Professor, Professor of the Department of World Economy Kyiv National University of Trade and Economics

\section{INTANGIBLE DETERMINANTS OF COMPETITIVENESS BETWEEN COUNTRIES DURING POST-INDUSTRIAL AGE: THE THEORETICAL ASPECT}

The purpose of the article. The relevance of the article research is conditioned by the spread of the latest public inquiry to popularize the idea of countries' success not only by the criteria of economic achievements, but also in a view of the importance of intangible determinants, in particular the global expansion of national cultures in broad sense. It is determined that through the age of total informatization intensive transcontinental displacement of labor, tourists, students, the active development of international production and distribution networks of source for national product formation goes beyond domestic markets and is characterized by complex set of exogenous and endogenous factors, resources and conditions. The hypothesis that in the postindustrial age the role of intangible factors of social reproduction will be strengthened against the background of weakening of the dominant value of the resource material component and factors of direct expansion has been formulated. The purpose of the study is to systematize theoretical approaches to the disclosure of the content of intangible factors in the formation of the competitive status of countries, to identify the mechanism of influence of soft power technologies on the competitiveness of countries within contemporary period of time.

Methodology. To reveal the theoretical and methodological principles of enhancing the role of intangible determinants of competitiveness of countries in the post-industrial age with the separation of their newest components (culture, education, brand of the country, etc.), combinatorics of procedural and institutional approaches were used (to estimate the status of "soft power" elements and exchange of powers to country ratings by international rankings); comparative analysis approach (to summarize successful regulatory practices aimed at enhancing intangible determinants to increase the competitiveness of the open economies).

Results. The results of the study showed that at present day there is no universally accepted interpretation of essence and content of the concept "soft power" as a component of intangible determinants of the competitive status of countries in foreign and domestic professional scientific literature and within expert environment, as well as the multivariate interpretation of it is revealed. By revealing external and internal determinants of the use of soft power technologies, their tactical and strategic goals, instruments and methods of implementation, the necessity of using intangible determinants as a priority means of making the country's image on the international arena has been identified. Foreign policy and authority in international affairs are defined as external determinants; position in the global hierarchy and geopolitical status of the country; civilization status, political and economic model of state development; state development strategy and ability to put it into practice; information resources of the country, its communicative mobility. Internal (socio-cultural) determinants are identified as ideology; style, quality and standard of living; values (including national idea); the mentality of the nation; culture of the country (art, literature, film industry, theater, show business); state's creative potential: the ability to generate ideas and technologies, including the creative power of the nation. On the basis of familiarization with the data of international rankings and statistics of national statistical services, the thesis about the effectiveness of the use of "soft power" in state policy of a number of countries (China, South Korea, some countries of BRICS, etc.) is substantiated.

Practical implications. The practical significance of the presented research is driven by the focus on improving the quality and validity of the decision-making system at the macro level in contemporary Ukraine, namely through methodological basis for the modernization of national strategy that reflects the latest trends in state regulation based on successful national regulatory frameworks. It is recommended that the national economic development strategy should cover the full range of components and factors, including intangible ones.

Value/originality. Identifying new quality determinants of enhancing international competitiveness of countries in the 21st century has made it possible to identify the link between targeted measures of national regulatory policies for the development and maintenance of intangible assets and the potential for transformation of countries' place in the international rating system. Prospects for further research are seen as in conducting economic and mathematical modeling based on statistics and estimations of international rankings of countries in order to identify the link between traditional (material) and new (intangible) factors of the state's competitive status formation and its change in the post-industrial era. 